\title{
A ORIENTAÇÃO AXIOLÓGICA SOBRE A ATUAÇÃO DO PROFESSOR DE LÍNGUA PORTUGUESA: UMA REFLEXÃO SOBRE O DISCURSO DA DESATUALIZAÇÃO DOCENTE*
}

\author{
LA ORIENTACIÓN AXIOLÓGICA SOBRE LA ACTUACIÓN DEL PROFESOR DE LENGUA PORTUGUESA: \\ UNA REFLEXIÓN SOBRE EL DISCURSO DE LA DESACTUALIZACIÓN DOCENTE
}

\section{THE AXIOLOGICAL GUIDANCE ON THE PERFORMANCE OF THE ENGLISH LANGUAGE TEACHER: A REFLECTION ON THE DISCOURSE OF OUTDATED TEACHING}

\author{
Nívea Rohling** \\ Universidade Tecnnológica Federal do Paraná - UTFPR, Câmpus Curitiba, BR
}

\begin{abstract}
RESUMO: Este artigo apresenta uma análise de produções discursivas de licenciandos de um curso de Letras-Português-EaD de uma universidade pública federal do sul do Brasil no que se refere à atuação do professor de Língua Portuguesa. A fundamentação teórico-metodológica insere-se nos estudos do Discurso do Círculo de Bakhtin. Os dados da pesquisa compõem-se de: 106 fóruns de discussão; 59 enunciados de atividades avaliativas, postados no ambiente virtual de ensino e aprendizagem no período de 2007 a 2011; e dados gerados por meio de um questionário, respondido por 61 licenciandos. A análise evidenciou um movimento dialógico de assimilação do discurso da desatualização docente na prática do professor como também um movimento dialógico de refutação a tais discursos.

PALAVRAS-CHAVE: formação inicial de professor; desatualização docente; análise dialógica do discurso.

RESUMEN: Este artículo presenta un análisis de producciones discursivas de pregrado de Letras-Portugués-EaD de una universidad pública federal del sur de Brasil a lo que se refiere a la actuación del profesor de Lengua Portuguesa. La base teóricometodológica se encuentra en los estudios del Discurso del Círculo de Bakhtin. Los datos de la investigación son compuestos de: 106 foros de discusión; 59 enunciados de actividades evaluativas, disponibles en el ambiente virtual de enseñanza y aprendizaje en el período de 2007 a 2011; los dados generados por medio de un cuestionario, contestado por 61 estudiantes de pregrado. El análisis evidenció un movimiento dialógico de asimilación del discurso de la desactualización docente en la práctica del profesor como también un movimiento dialógico de refutación a tales discursos.

PALABRAS CLAVE: formación inicial de profesor; desactualización docente; análisis dialógica del discurso.
\end{abstract}

ABSTRACT: This article presents an analysis of discursive productions of undergraduates of a Bachelor's Portuguese-DE course from a public university in southern Brazil in relation to the performance of the Portuguese teacher. The theoretical and methodological foundation is part of the studies of the speech of the Bakhtin Circle. The survey data consists of: 106 discussion forums; 59 set of evaluative activities posted in the virtual environment for teaching and learning in the period 2007-2011; and data generated by means of a questionnaire answered by 61 undergraduates. The analysis showed a dialogic movement of assimilation of the discourse of teaching downgrade in teacher practice as well as a dialogical movement rebuttal to such discourses. KEYWORDS: teacher training; outdated teaching; dialogic discourse analysis.

\section{INTRODUÇÃO}

O discurso sobre a desatualização do professor foi constituído nos processos históricos da esfera escolar. Magda Soares (2002), ao historiar a constituição da disciplina de Língua Portuguesa (doravante LP) no Brasil, aponta que, a partir da década de 1950, com a entrada de filhos das camadas populares na escola, multiplicou-se o número de alunos, o que acarretou um amplo (e menos seletivo) recrutamento de professores de LP. Os professores já não tinham o perfil anterior -quando a escola era destinada aos filhosfamília (filhos da burguesia) -, de "[...] um estudioso da língua e de sua literatura que se dedicava também ao ensino" (SOARES, 2002, p. 166). Mais ou menos a partir desse período, transferiu-se ao autor do livro didático a função de formular as aulas (o que inclui plano de aula, provas, exercícios, etc.).

\footnotetext{
* Este tex to é resultado de uma pesquisa de doutoramento desenvolvida no Programa de Pós-Graduação em Linguística da Universidade Federal de Santa Catarina (UFSC) com financiamento do CNPq, sob a orientação da Profa. Dra. Rosângela Hammes Rodrigues.

** Doutora em Linguística pela UFSC (2012); docente do Departamento Acadêmico de Comunicação e Expressão da UTFPR/Câmpus Curitiba. Coordenadora do Grupo de Pesquisa em Linguística Aplicada (GRUPLA). E-mail: niveajoi@yahoo.com.br.
} 
Conforme a pesquisadora foi nessa época que

[...] se intensifica a depreciação da função docente: a necessidade de recrutamento mais amplo e menos seletivo de professores [...] resultado da multiplicação de alunos, vai conduzindo a rebaixamento salarial e, consequentemente, a precárias condições de trabalho, o que obriga os professores a buscar estratégias de facilitação de sua atividade docente. (SOARES, 2002, p. 167).

De forma semelhante, Franchi (2006[1987]) problematiza o ensino de língua na escola e pondera sobre as condições de trabalho dos professores. De acordo com Franchi, os professores "lecionam em um regime de trabalho injusto e a baixíssimos salários: não lhes dão condições e tempo de preparo de suas aulas e de um estudo sistemático. Todos, mesmo os que se esforçam por organizá-los, sabem que não bastam cursinhos intensivos de reciclagem" (FRANCHI, 2006[1987], p. 35-36).

Desse modo, é perceptível que, no processo histórico da constituição da disciplina de LP, ocorre uma desvalorização do professor e um desestímulo à profissão. $O$ discurso da desatualização docente e, consequentemente, o da desvalorização do profissional professor vem-se constituindo historicamente a partir das condições materiais precárias que lhe são impostas. Tal discurso, certamente, atravessa os muros da escola, sendo, pois, reenunciado e reacentuado pelos sujeitos desta pesquisa (licenciandos em Letras).

Inserido em um contex to de reflexão epistemológica acerca da constituição identitária do professor de LP, este estudo problematiza as orientações axiológicas discursivizadas por licenciados em Letras-Português, na modalidade a distância, de uma universidade pública do sul do Brasil no tocante à atuação docente, destacando o discurso sobre a desatualização docente do professor.

Para tanto, tomamos como base epistêmica e metodológica a concepção bakhtiniana de linguagem, de discurso e de enunciado (BAKHTIN, 1998[1975]; BAKHTIN, 2003[1979]; BAKHTIN [VOLOCHÍNOV], 2004[1929]). Os dados da pesquisa compõem-se de: 106 fóruns de discussão; 59 enunciados de atividades avaliativas, postados no ambiente virtual de ensino e aprendizagem no período de 2007 a 2011; e dados gerados por meio de um questionário, respondido por 61 licenciandos, participantes da pesquisa.

Em seguida, apresentamos as regularidades encontradas no processo de análise dos dados, a fim de refletir sobre os modos como o professor de LP é discursivizado na formação inicial.

\section{O DISCURSO SOBRE A DESATUALIZAÇÃO DO PROFESSOR}

Os licenciandos, sujeitos da pesquisa, valoram a relação entre o professor e o conhecimento, seja o teórico, seja o de ensino e aprendizagem em sala de aula, considerando-o como constitutivo para a formação desse profissional. Ao discursivizar a relação entre o professor e o conhecimento, destacou-se a reenunciação de discursos depreciativos a respeito desse profissional, mais precisamente sobre a desatualização teórica e profissional do professor.

Na reenunciação desses já-ditos, há enunciados que estabelecem um movimento dialógico de assimilação (R. H. RODRIGUES, 2001) desses discursos e também enunciados que respondem a esses discursos depreciativos de modo a questioná-los ou refutá-los, evidenciando um movimento dialógico de distanciamento ( $\mathrm{R}$. $\mathrm{H}$. RODRIGUES, 2001).

Os discursos depreciativos sobre o professor, reenunciados pelos licenciandos, ancoram-se nos já-ditos sobre o professor, constituídos na história das disciplinas escolares 3e relacionam a desatualização docente à crise no ensino de LP. Muitas vezes, os discursos dos licenciandos restringem as críticas ao ensino de LP à relação entre o professor e o conhecimento, remetendo ao professor (e somente a ele) a culpa pelo não saber os conteúdos que deve ensinar.

A seguir evidenciamos a reenunciação do discurso depreciativo sobre a desatualização docente, acentuando a identidade do professor desatualizado.

De maneira geral, como você vê o professor de Língua Portuguesa hoje? O que é ser professor de Lingua Portuguesa hoje? 
Q1:' Uma responsabilidade enorme. Mas creio que ser professor de L.P. seja muito mais que passar conteúdos repetitivos/mecânicos. É ser um apaixonado pela língua, pelo ensino e por pessoas.

Q2: O professor de Lingua Portuguesa está meio ultrapassado precisa se inserir melhor no contexto atual.

Q3: Com um grande papel e responsabilidade - e esta tarefa vai além de transmitir conhecimento(s)... e, hoje, ainda encontramos professores c/ concepções lá da década de $70 .$.

O discurso depreciativo sobre a desatualização do professor se evidencia por meio das escolhas lexicais (passar conteúdos repetitivos/mecânicos ou transmissão de conhecimentos, ultrapassado) e de afirmações como: o professor é alguém que precisa se inserir melhor no contexto atual, ou que tem concepções lá da década de 70. Esse discurso incide sobre os modos de olhar a atuação do professor de LP na formação inicial. Segundo Geraldi (2010), a redução do professor para a identidade de alguém que repassa o que sabe gera um grande problema: instaura-se na identidade desse profissional o signo da desatualização, porque "como o professor não está produzindo os saberes que ensina, ele está sempre atrás destes saberes que estão sendo produzidos por outros" (GERALDI, 2010, p. 85).

O discurso da desatualização está imbricado ao discurso do professor mediador, como se pode observar a seguir:

De maneira geral, como você vê o professor de Lingua Portuguesa hoje? O que é ser professor de Lingua Portuguesa hoje?

Q4: Talves os professores de hoje precisariam se manter atualizados e ensinar conforme o que requer o ensino de hoje. Precisa ser um mediador junto a seus alunos.

Q5: Hoje ainda despreparado para desenvolver o trabalho. É reconhecer o seu papel como mediador do processo respeitando as diferenças culturais e históricas e regionais e buscar sempre a capacitação em serviço pois ninguém se forma professor a educação é continuada ao longo do processo de trabalhar também o de estudar.

Em Q4 e Q5 o discurso da desatualização (despreparado; precisariam se manter atualizados) mostra-se imbricado ao discurso do professor mediador, apontando para dois polos avaliativos: a) o professor despreparado/desatualizado, que corresponderia à realidade; b) o professor mediador, que seria o perfil, a identidade desejável do professor. Ao afirmar que é necessário ensinar conforme o que requer o ensino de hoje, materializa-se um acento depreciativo que aponta o professor como aquele que está sempre atrasado ou desatualizado, um sujeito que parece não viver o seu tempo. Já na enunciação do professor como mediador, há a posição axiológica da defesa de um novo jeito de ensinar (conforme o que requer ensino de hoje), mas que também não é explicitado/explicado pelo licenciando, o que pode remeter à compreensão do professor mediador como transmissor de conteúdos.

Ao falar da desatualização do professor, o licenciando traz a noção do professor mediador, pois se o professor é concebido como alguém que se interpõe entre o aluno e o objeto de conhecimento, ele precisaria, nessa concepção, constantemente se abastecer de novos conteúdos, que não são estáticos. Em outras palavras, a relação entre o professor mediador e o professor desatualizado/despreparado é reenunciada pelos licenciandos de forma interligada porque o professor mediador é compreendido, discursivizado e valorado no sentido de interposição entre o aluno e o conhecimento a ser mediado. Nessa perspectiva, o professor precisa, sim, atualizar-se/reciclar-se, abastecer-se sempre de novos conteúdos a serem mediados, melhor dizendo, transpostos para a aula de LP. O discurso sobre a desatualização docente está, pois, assentado na "crença de que 'ser professor' é desatualizar-se no trabalho, desqualificar-se depois que fora dado por habilitado" (GERALDI, 2002[1991], p. XVII).

No movimento de reenunciar o discurso da desatualização do professor, um dos licenciandos acentua essa valoração negativa, conforme observamos a seguir:

De maneira geral, como você vê o professor de Língua Portuguesa hoje? O que é ser professor de Lingua Portuguesa hoje?

\footnotetext{
${ }^{1}$ Os dados analisados correspondem exatamente ao que foi textualizado pelos sujeitos da pesquisa, ou seja, não houve nenhuma espécie de revisão de texto. Para indicar a natureza do dado inserido na análise são utilizadas as seguintes siglas: AA - Atividades Avaliativas; F-Fórum; e Q Questionário. Cabe destacar que os nomes mencionados na transcrição dos dados são fictícios.
} 
Q6: Há uma diferença gigante entre o que é e o que deveria ser. O que existe são professores despreparados, descomprometidos e desatualizados, em grande parte das escolas. No entanto, um professor de LP deve ter em mente os objetivos pelas quais ministra suas aulas. É necessário ter conteúdo e saber aplicá-lo, respeitando a cultura e as características de cada aluno.

O discurso depreciativo sobre o professor se intensifica nesse enunciado, como podemos observar em: $O$ que existe são professores despreparados, descomprometidos e desatualizados. Aqui está posta uma acentuação do discurso depreciativo em relação ao professor, tão recorrente em várias esferas: o professor é desatualizado; é despreparado; não lê PCNs, é descomprometido, etc. E, ao reenunciar esse discurso, revela-se no enunciado do licenciando um tom incisivo que marca certeza (Há uma diferença gigante entre o que é e o que deveria ser. O que existe são professores despreparados, descomprometidos e desatualizados, em grande parte das escolas). O licenciando assume esse discurso, apontando para um movimento dialógico de assimilação (R. H. RODRIGUES, 2001) ao discurso da desatualização docente.

Destacamos uma outra situação de interação em que emerge o discurso da desatualização docente, trata-se da atividade avaliativa desenvolvida na disciplina de Linguística Aplicada: Ensino de Língua Materna (2011/1), que consistia na produção de um ensaio. Apresentamos, a seguir, somente os enunciados das tiras que compuseram a referida atividade.

Figura 1- Atividade avaliativa: tiras de Mafalda
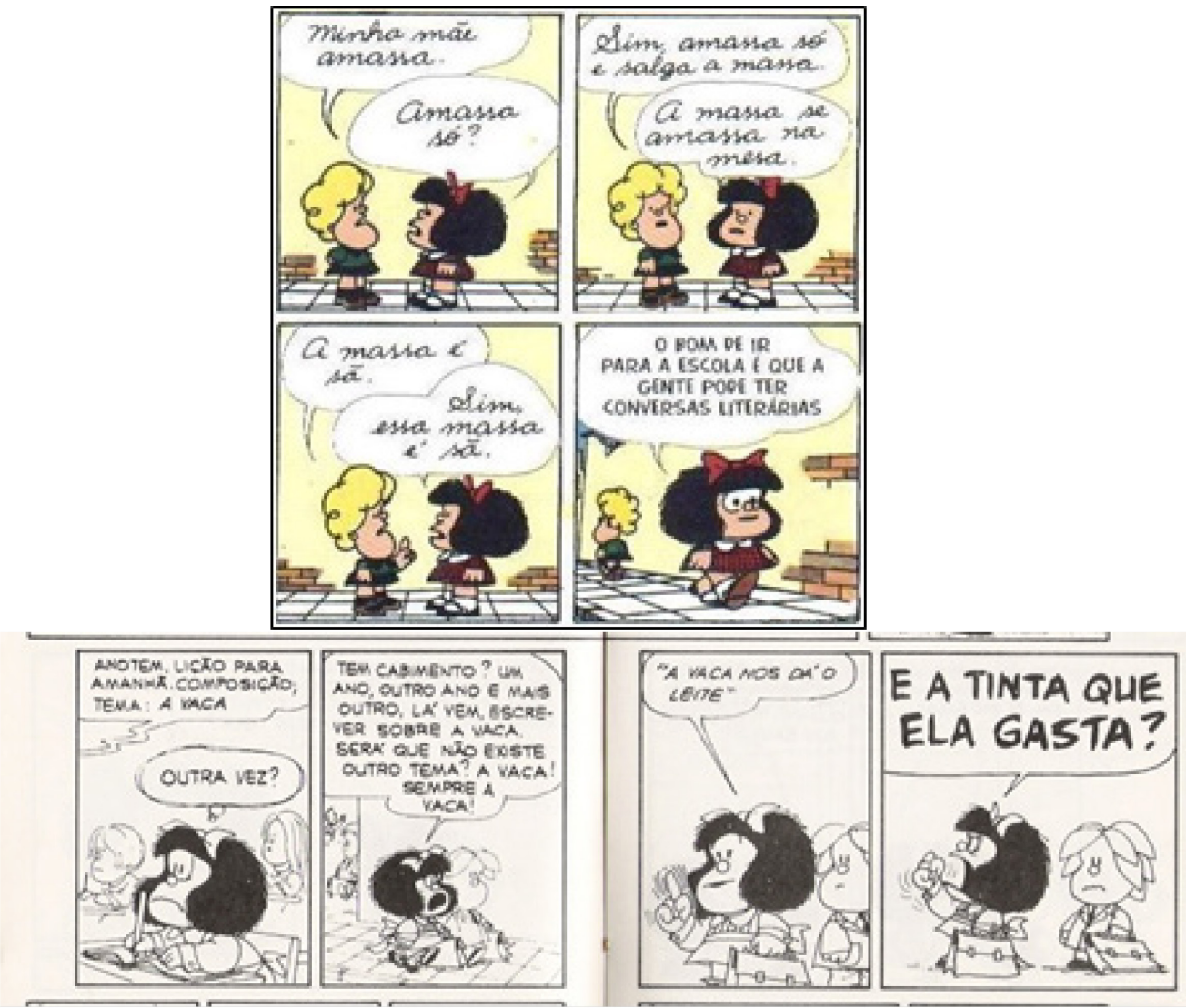

A atividade avaliativa é, de certo modo, uma solicitação de contrapalavras dos licenciandos ao que foi proposto como objeto de ensino e aprendizagem nas discussões da disciplina. Tendo em vista que, após tematizar esses objetos do discurso no contexto da disciplina (as teorias de letramento, a concepção dialógica da linguagem e as concepções de linguagem, de texto e de ensino da leitura e da escrita na escola), a atividade solicitava que os licenciandos analisassem as situações apresentadas, nas tiras de Mafalda e no vídeo de desenho animado Ruca ${ }^{2}$, a fim discutir aspectos relacionados às práticas de letramento escolar e familiar, sob a perspectiva teórica que balizava a disciplina.

\footnotetext{
2 O vídeo, objeto de análise da atividade proposta, pode ser visualizado em: <http://www.youtube.com/watch?v=9_CqMp16ZWo \&playnext=1\&list $=$ PL4EA5B99FF983FBB2 $>$.
} 
Ao serem solicitados a falar sobre as situações apresentadas nesses enunciados (tiras e desenho animado), a partir de um determinado lugar teórico (das teorias que embasam a disciplina em questão), alguns licenciandos trazem sua contrapalavra acentuada/valorada/balizada por um horizonte apreciativo diferente do que era então tematizado na disciplina. Em suas contrapalavras, emergem discursos outros que não têm ancoragem no discurso teórico. Nessa situação de interação, novamente ressoam vozes sociais (já-ditos) que significam/acentuam fortemente o discurso da desatualização do professor.

AA1-Ester: As tiras em análise nos remetem à velha história do professor do caderno amarelo, ano após ano, ele continua com o mesmo método de trabalho, com suas velhas aulinhas já semiprontas e não tem visão do que ocorre no mundo a sua volta, principalmente no mundo de seus alunos que evoluem, crescem intelectualmente, interagem com essa realidade extra vida escolar.

Ester conclui que a equipe da disciplina está mostrando um discurso crítico em relação à atuação do professor, já que o conteúdo das duas tiras aponta nessa direção. No entanto, nessa situação de interação, a equipe da disciplina não tinha em foco a desatualização docente e sim a discussão sobre as concepções de linguagem e de texto que são retratadas nas tiras. Mas o fato é que a licencianda assume o tom crítico na sua resposta a fim de reenunciar o discurso da desatualização docente. Ela reenuncia o discurso da desatualização do professor de modo a produzir um sentido de naturalidade, ou melhor, sinaliza uma cristalização dessa perspectiva, como se observa em: nos remetem à velha história do professor do caderno amarelo. A acentuação (o tom) aponta para o movimento dialógico de assimilação dessa valoração depreciativa em relação à atuação do professor. A assimilação do discurso sobre a desatualização do professor se faz na contraposição às práticas consideradas tradicionais, que é o que baliza o próprio autor das tiras em análise. Desse modo, o discurso da desatualização é utilizado pela licencianda para refutar e se distanciar das práticas de ensino tradicionais. Para isso, usa estratégias de enquadramento discursivo a partir dos recursos como os apontados por R. H. Rodrigues (2001, p. 176): "o uso de palavras e expressões avaliativas, a negação, as aspas, os operadores argumentativos, o chamamento do discurso de outro, a ironia, os pronomes demonstrativos".

De acordo com R. H. Rodrigues (2001, p. 177),

[… no movimento dialógico de distanciamento, o uso de adjetivos ou outras palavras e expressões qualificadoras [como é o caso de "velha história"] é uma estratégia muito freqüente, pois cria um enquadramento negativo ou de distanciamento (desqualificação) em relação ao outro e a sua fala.

Ao enunciar a expressão velha história, a licencianda enuncia um movimento dialógico de distanciamento (R. H. RODRIGUES, 2001) em relação às práticas do professor, que considera tradicionais e ultrapassadas. Ao mesmo tempo, mostra a adesão ao discurso da desatualização do professor, uma vez que reafirma esse tom depreciativo ao pontuar a diferença entre professores e alunos: [...] no mundo de seus alunos que evoluem, crescem intelectualmente, interagem com essa realidade extra vida escolar. Assim, o enunciado da licencianda endossa, corrobora e enfatiza o discurso já-dito sobre a desatualização do professor.

De modo geral, alguns enunciados atribuem a culpa da desatualização ao próprio professor (ou seja, de forma individual). Nessa visão, é o professor que não busca "atualizar-se". Não percebem os já-ditos depreciativos sobre a docência como um discurso mais amplo, como uma identidade construída nos processos históricos na esfera escolar e demais esferas de atividades humanas, que é intrinsecamente ligada às condições materiais impostas ao profissional professor.

\section{O PROFESSOR E AS CONTINGÊNCIAS DA PRÁTICA}

Na seção anterior analisamos os enunciados em que se evidenciam, de modo mais acentuado, o discurso da desatualização do professor. Nesta seção, discorremos sobre as produções discursivas em que os sujeitos apresentam uma compreensão mais situada/crítica sobre o professor. Tais enunciados levam em consideração as contingências dos dispositivos escolares na atuação do professor de LP, como mostramos na sequência.

De maneira geral, como você vê o professor de Lingua Portuguesa hoje? O que é ser professor de Língua Portuguesa hoje? 
Q7: Vejo que o professor de LP como de outras disciplinas tem uma função muito importante, mas que na maioria das vezes é dificultada ou mesmo desvalorizada pelo próprio sistema de ensino, o que desmotiva a atuação enquanto professor.

Que fatores intervêm nos modos de organização escolar e na prática pedagógica dos professores?

AA2-Marcia: Citar fatores que intervém nos modos de organização escolar e na prática pedagógica dos professores não é difícil, porém, as atitudes custam a fanhar fôlego e dar resultado. No meu modo de pensar, o modelo de ensino está muito aquém do que a educação exige. As salas superlotadas, alunos sem iniciativa e indisciplinados, os professores desmotivados financeiramente, as escolas desatualizadas, dentre outros. Isso contribui de forma significativamente no desenvolvimento do ensino aprendizagem, principalmente da Lingua Portuguesa [...].

O discurso-resposta do licenciando $(\mathrm{Q} 7)$ mostra um entendimento de que a atuação do professor, no interior da aula, está ligada ao que lhe é exterior, ou seja, a condições materiais/concretas que, no caso em questão, podem dificultar e desmotivar o professor. Semelhantemente, Márcia (AA2) tece uma reflexão mais ampla sobre as problemáticas no ensino. Esse enunciado é motivado pela atividade proposta na disciplina de Metodologia do Ensino de Língua Portuguesa e Literatura, que fez os licenciandos refletirem sobre os fatores que incidem na prática pedagógica do professor. Ela enfatiza seu enunciado-resposta e não somente reenuncia o discurso dos documentos oficiais de ensino (que balizaram a discussão desta atividade avaliativa), como vemos em: No meu modo de pensar, o modelo de ensino está muito aquém do que a educação exige. A licencianda assume e se compromete com o que está dizendo (no meu modo de pensar). A sua reflexão não deposita a culpa da crise no ensino de Língua Portuguesa na desatualização ou no despreparo do professor. Ao contrário, aponta outros fatores e menciona o professor como um deles (As salas superlotadas, alunos sem iniciativa e indisciplinados, os professores desmotivados financeiramente, as escolas desatualizadas, dentre outros.). Ao salientar os fatores que interferem na prática pedagógica, no que se refere ao professor, menciona as condições materiais impostas a esse profissional (professores desmotivados financeiramente). Em outras palavras, não há um movimento de culpabilizar o professor (ou apenas o professor), como evidenciado antes.

Esses enunciados (Q7; AA2) remetem-nos à reflexão de Geraldi (2010, p. 55), quando afirma que os acontecimentos da sala de aula são atravessados pelo que lhe é exterior, pois as concepções educacionais, as propostas de ensino, as políticas de ensino e os projetos de pesquisa, etc., que se concretizam no interior escola, são definidos no seu exterior, no âmbito mais amplo da formação social.

Em um dos fóruns houve uma situação de interação em que os licenciandos assumem também uma posição de questionamento/refutação/distanciamento dos discursos depreciativos sobre o professor. A discussão foi motivada por uma das leituras propostas pela disciplina Metodologia do Ensino de Língua Portuguesa e Literatura, que provocou uma das licenciandas a se manifestar no fórum:

\begin{tabular}{l}
\hline F1 \\
Re: Fórum tira-dúvidas de Pato Branco \\
por Meri - domingo, 10 abril $2011,16: 18$ \\
Prof. \\
Estive lendo o $1^{\circ}$ capítulo e surgiram algumas algumas questões que figuei meio pensativa. Poderia me \\
esclarecer essas questões? \\
Poderia me explicar porque a profissão, professor, é tão criticada e de pouco prestígio em nossa \\
sociedade? [...]
\end{tabular}

Meri (F1) indaga sobre os motivos da depreciação da profissão do professor, como vemos em: Poderia me explicar porque a profissão, professor, é tão criticada e de pouco prestígio em nossa sociedade? Embora a licencianda não se refira especificamente ao discurso sobre a desatualização do professor, que vimos discutindo até aqui, podemos considerar que, ao mencionar o pouco prestígio da profissão, ela se refere de modo geral a uma série de discursos que depreciam essa profissão, entre eles o da desatualização docente.

O discurso já-dito sobre a depreciação do professor, reenunciado pela licencianda, não se manifesta como uma certeza, uma verdade ou uma cristalização, ou como um discurso assumido pela licencianda, como nos exemplos anteriores. O tom é outro; há um anseio de compreender as origens de tais discursos, enfim, de problematizá-los. 
O questionamento de Meri provoca uma reação-resposta ativa em uma das colegas, que escreve:

\begin{tabular}{l}
\hline F2 \\
Re: Fórum tira-dúvidas de Pato Branco \\
por Suzy - domingo, 10 abril $2011,22: 45$ \\
Olá, \\
Acabei de assistir o vídeo sobre "O perigo da história única"... de Chimamanda Adichie, \\
É isso, mesmo... ela faz passar um filme em nossa mente.... \\
Simplesmente, interessante! \\
Suzy.
\end{tabular}

O discurso de Meri (F1) toca Suzy (F2), fazendo emergir novas relações dialógicas, uma vez que Suzy relaciona os discursos já-ditos depreciativos sobre a atuação docente ao vídeo postado no hipertexto da disciplina da disciplina de Metodologia do Ensino de Língua Portuguesa e Literatura (Acabei de assistir o vídeo sobre "O perigo da história única"... de Chimamanda Adichie.). A relação dialógica entre o questionamento de Meri e o conteúdo do vídeo não é materializada de forma explícita por Suzy, como vemos em: É isso, mesmo... ela faz passar um filme em nossa mente... Simplismente, interessnte! Mas os interlocutores da situação de interação conseguem atribuir sentido ao enunciado de Suzy; entendem o que Suzy quer dizer com o uso de reticências, com as frases incompletas. Os interlocutores que assistiram ao vídeo compreendem que Suzy estabelece uma relação entre as visões estereotipadas sobre o professor (discursos já-ditos depreciativos) e os estereótipos que mostram uma visão de mundo hegemônica, conforme discutido no vídeo. O vídeo mencionado pela licencianda constitui um relato da escritora nigeriana Chimamanda Adichie ${ }^{3}$, que discorre sobre o modo de construir uma única versão da história de diferentes culturas. Nesse enunciado, a escritora critica a visão hegemônica da classe dominante, que elabora e faz circular visões estereotipadas de mundo. Embora o discurso da escritora tematize primordialmente questões de etnia e classe social, a licencianda estabelece um diálogo entre os modos de contar uma história única (dos africanos, mexicanos, etc.) com os discursos depreciativos acerca da profissão docente, quando afirma: ela fa z passar um filme em nossa mente.

O que Bakhtin[Volochínov] (1926) diz sobre o contexto extraverbal, que é parte constitutiva do enunciado, pode ser aqui reenunciado para que se compreenda melhor as relações dialógicas estabelecidas entre as licenciadas no fórum. Segundo Bakhtin (1926, p. 9), “[ [...] o enunciado concreto (e não a abstração lingüística) nasce, vive e morre no processo da interação social entre os participantes da enunciação. Sua forma e significado são determinados basicamente pela forma e caráter desta interação". Nessa interação realizada no fórum, destacamos a situação extraverbal do enunciado que, de acordo com Bakhtin [Volochínov] (1926), compreende três fatores: 1) o horizonte espacial comum dos interlocutores; 2) o conhecimento e a compreensão comum da situação por parte dos interlocutores e 3) sua avaliação comum dessa situação.

No caso dos enunciados em discussão, temos um horizonte espacial e temporal comum aos interlocutores, o fórum inserido na aula virtual na disciplina de Metodologia do Ensino de Língua Portuguesa e Literatura. Os interlocutores compartilham a situação e sabem que estão inseridos em um fórum permeado por discussões acerca da atuação do professor, onde emerge um discurso já-dito que se torna nesse contexto objeto do discurso: o desprestígio da profissão de professor. O horizonte aperceptivo/avaliativo dos interlocutores mostra-se em seus enunciados e apresenta um tom contestador a esses discursos já-ditos acerca da depreciação docente, já que há uma posição de defesa da profissão de professor. Contudo, essa defesa não é explicitada verbalmente, uma vez que Suzy não se posiciona explicitamente acerca dos estereótipos sobre o professor. No entanto, ela marca seu posicionamento crítico face a esses discursos de outro modo, por meio da referência a um outro enunciado (vídeo), que funciona, no caso da resposta de Suzy, como um discurso bivocalizado (BAKHTIN, 2008[1963]), uma vez que, ao enquadrar o discurso da escritora no referido vídeo sobre "as verdades únicas", a aluna se enuncia a partir desse discurso. Em outras palavras, o discurso da escritora nigeriana é enquadrado no horizonte valorativo da licencianda a fim de

\footnotetext{
${ }^{3}$ Disponível em: <http://www.youtube.com/results? search_query=o+perigo + de + uma $+\%$ C3\%BAnica + hist $\%$ C3 $\%$ B3ria\&oq $=0+$ perigo + de + uma + \%C3\%BAnica+\&aq=0\&aqi=g2\&aql=1\&gs_sm=c\&gs_upl=444519854lol 12020l2212 1lolsl81 113181184916.3.3.111310>. Acesso em: $10 / 11 / 2011$.
} 
cumprir o seu projeto de dizer, que é o de que os estereótipos sobre o professor são também assentados em uma história única, a partir de um discurso hegemônico sobre a desvalorização docente.

Conforme aponta Bakhtin (2003[1979]), as relações dialógicas não podem ser reduzidas a relações meramente lógicas nem linguísticas, sendo possíveis, somente, entre enunciados integrais de diferentes sujeitos do discurso. Segundo Bakhtin:

[…] são relações (semânticas) entre toda espécie de enunciados na comunicação discursiva. Dois enunciados, quaisquer que sejam, se confrontados em um plano de sentido (não como objetos e não como exemplos lingüísticos), acabam em relação dialógica. (BAKHTIN, 2003[1979], p. 323).

Isso se mostrou no mesmo fórum, quando o diálogo entre as licenciandas suscitou outra contrapalavra, ainda mais provocativa sobre a depreciação da profissão de professor.

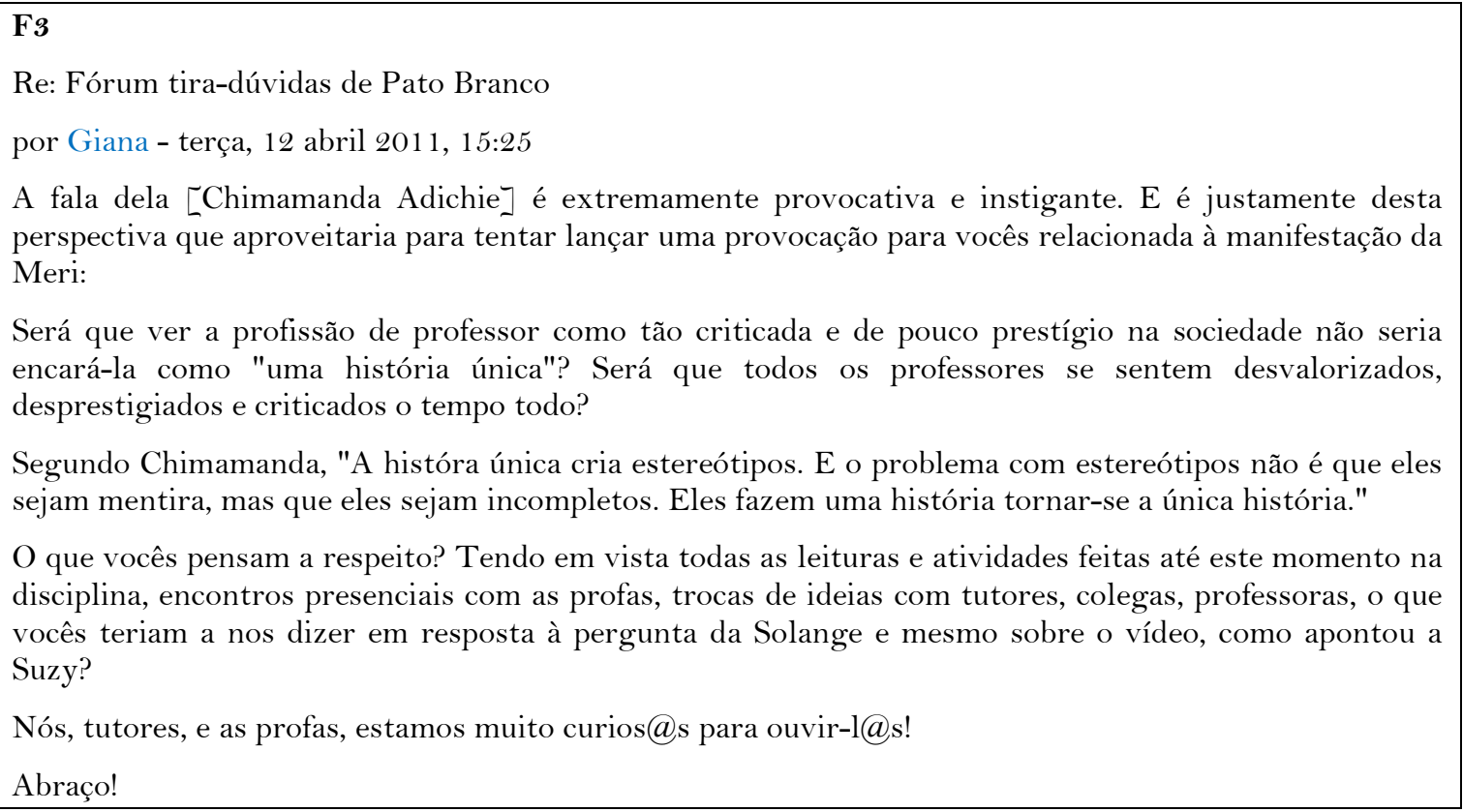

Esse enunciado é a reação-resposta de uma das tutoras a distância (Giana) ao questionamento de Meri (F1) a um outro tutor responsável pelo fórum e à postagem de Suzy (F2). O questionamento de Meri (Estive lendo o $1^{\circ}$ capítulo e surgiram algumas algumas questões que figuei meio pensativa. Poderia me esclarecer essas questões?) não é endereçado à tutora que se manifesta no fórum (F3). Embora não seja a tutora responsável pelo polo em questão, ela é tocada/provocada pela pergunta da licencianda (F1). A partir de seu olhar de professor, a tutora observa naquela situação de interação um lugar propício para reflexão sobre questões relacionadas à docência. Isso a motiva a se manifestar acerca do discurso depreciativo da profissão de professor, como vemos em: Será que ver a profissão de professor como tão criticada e de pouco prestígio na sociedade não seria encará-la como "uma história única"? Será que todos os professores se sentem desvalorizados, desprestigiados e criticados o tempo todo? Segundo Chimamanda, "A históra única cria estereótipos. E o problema com estereótipos não é que eles sejam mentira, mas que eles sejam incompletos. Eles fazem uma história tornar-se a única história.".

A sua reflexão dialoga com a fala das licenciandas, sobretudo com a de Suzy, que menciona o vídeo da escritora nigeriana. O discurso-resposta da tutora mostra a relação dialógica entre os estereótipos sobre os professores e os estereótipos mencionados pela escritora no vídeo. Na situação de interação relatada, podemos dizer que a relação semântica recai sobre o termo estereótipo. De acordo com Bakhtin (2003 [1979], p. 292, grifos do autor), "quando escolhemos as palavras no processo de construção de um enunciado, nem de longe as tomamos sempre do sistema da língua em sua forma neutra, lexográfica. Costumamos tirá-las de outros enunciados [...]". É no termo estereótipo, e toda a valoração/tom implicada nesse signo, que se encontra, no plano do sentido, o que é proferido no fórum da disciplina e o que é dito no vídeo pela escritora, uma vez que ambos tematizam os estereótipos constituídos por histórias únicas. 
Novamente o enunciado do vídeo é intercalado (BAKHTIN, 2003[1979]) nessa interação; ele é tomado como objeto de discurso das interlocutoras. A tutora reenuncia o discurso da escritora na sua fala. Nos termos bakhtinianos, temos "o discurso de outrem na linguagem de outrem" (BAKHTIN, 1998[1975], p. 127, grifo do autor). O discurso bivocal entrelaça a voz da tutora à voz da escritora nigeriana e concede ao enunciado pinçado um tom apreciativo de adesão, uma vez que o reconhece (o discurso da escritora) como parâmetro para cumprir a sua finalidade discursiva, ou seja, seu projeto de dizer.

Na sequência, a partir desse entrelaçamento de vozes, a tutora convoca os licenciandos a uma reflexão: Será que todos os professores se sentem desvalorizados, desprestigiados e criticados o tempo todo? Ela se posiciona a partir da perspectiva do professor, questiona sobre como o professor se vê (sua reação-resposta) face aos discursos insistentes e depreciativos sobre sua profissão. Podemos observar que a tutora não oferece uma resposta pontual para a pergunta feita por Meri (F1) sobre as origens desses discursos estereotipados sobre o professor. Ao contrário, a tutora convoca os demais licenciandos a refletir e a se posicionar sobre o tema. Convida-os/chama-os ao diálogo ( $O$ que vocês pensam a respeito? Tendo em vista todas as leituras e atividades feitas até este momento na disciplina, encontros presenciais com as profas, trocas de ideias com tutores, colegas, professoras, o que vocês teriam a nos dizer em resposta à pergunta da Meri e mesmo sobre o vídeo, como apontou a Suzy? Nós, tutores, e as profas, estamosmuito curios@s para ouvir-l@s!..).

No entanto, ao analisar as reações-respostas que se seguem no fórum, verificamos que os licenciandos não respondem ao questionamento da tutora ( $O$ que vocês pensam a respeito?). Há um silêncio, já que as manifestações subsequentes dos licenciandos no fórum não retomam o questionamento dirigido a eles de forma tão direta pela tutora. O fato é que a palavra da tutora é ignorada; os licenciandos passam a discutir questões outras, mais ligadas aos expedientes avaliativos da disciplina de como, por exemplo, prazos de entrega de atividades, normas para a escrita dos textos, etc.

Enfim, observamos que nenhum dos licenciandos se engajou no diálogo proposto pela tutora. Em uma perspectiva bakhtiniana, o que podemos dizer é que o não-dizer (o silêncio) também significa; e, no caso em questão, a prioridade na visão dos licenciandos era discutir os expedientes avaliativos da disciplina.

\section{4 À GUISA DE CONCLUSÃO}

A reflexão apresentada neste texto mostrou que o professor é discursivizado, na escola e em tantas outras esferas, de forma depreciativa. De modo geral, são enunciados que focalizam o professor como um profissional desatualizado em relação aos conhecimentos que precisa agenciar em sala de aula e também como alguém que não compreende as novas demandas do ensino hoje. Apontam um profissional que está em descompasso com as novas metodologias e conteúdos de ensino.

Isso tem relação com a seguinte reflexão de N. C. Rodrigues (2011):

Neste início de século XXI, estamos vivendo uma época em que o professor é um profissional desacreditado, alvo de um discurso ideológico hegemônico, fundamentado nos resultados dos indicadores alardeados pela mídia, que responsabilizam o professor pelos fracassos da educação e desqualificam seu trabalho cotidianamente. (N. C. RODRIGUES, 2011, p. 201).

Tais discursos são constituídos no interior das relações materiais, políticas e ideológicas, materializadas nas contingências da profissão como salários aviltantes, opressão por parte dos gestores e cerceamento da voz do professor.

Sobre essa questão, podemos encontrar aporte em Baltar (2011), que discute as condições da profissão de professor:

[…] é preciso dizer que estou ciente de que a caminhada não é para 'tímidos'. Principalmente se cotejarmos a quantidade e a complexidade dos problemas que enfrentam o dispositivo escolar. Professores desmotivados com alta carga de trabalho, salários aviltantes, opressão de modelos autoritários de gestão - seja pelo corpo diretivo da escola que não abre espaço para o trabalho colegiado, seja pelo aparelho burocrático mantenedor do sistema - secretarias de educação estaduais e municipais, precariedades infraestruturais, ambiente de competição entre colegas de trabalho, insegurança e medo diante da violência social que penetra os muros da escola etc. (BALTAR, 2011, p. 8). 
Certamente as condições materiais concretas mencionadas pelos pesquisadores são preponderantes na expropriação do professor não só de seus salários, mas de suas crenças e identidades (GERALDI, 2002 [1991], p. XXVII). A reenunciação desses discursos no interior da formação inicial, proferida por sujeitos que são futuros professores, cria uma circularidade discursiva que, ao passo em que é reafirmada, engrandece-se, ganha força e assume status de verdade (única), ou seja, de estereótipo. Trata-se, pois, da inculcação da ideologia da incompetência, que historicamente tem-se instalado na profissão de professor, conforme discute Geraldi já no início da década de 1990 (GERALDI, 2002[1991], p. XX).

Não se trata de culpabilizar os licenciandos por reenunciarem tais discursos. Ao contrário, pensamos que a problematização dos discursos depreciativos sobre a profissão de professor pode mostrar o quão urgente é o compromisso dos formadores em construir inteligibilidades que apontem para uma outra identidade para o professor. É urgente que, na formação inicial, seja discursivizada uma memória de futuro pautada em um outro modo de ver a profissão de professor.

A análise dos dados evidenciou que, em algumas situações de interação no curso, como, por exemplo, no fórum de discussão da disciplina Metodologia do Ensino de Língua Portuguesa e Literatura e também em uma das atividades avaliativas dessa mesma disciplina, foi possível problematizar a atuação do professor sob outra perspectiva, de modo mais situado, não mais depositando no professor toda a responsabilidade da instauração da crise na escola. $\mathrm{O}$ que nos mostra que a formação inicial pode sim constituir-se como um lugar de ressignificação do horizonte valorativo constituído historicamente em torno da profissão de professor. A formação inicial (e continuada) do professor pode (e deve) se configurar como um lugar de questionamento e problematização de tais discursos sobre a docência a partir de um olhar mais analítico e menos conformado pelo discurso hegemônico.

É preciso operar mudanças significativas nas maneiras de se referir a esse profissional, reestabelecendo ou estabelecendo um novo lugar para o professor. Obviamente, isso demanda que sejam satisfeitas também as condições materiais, como melhores condições de trabalho, melhores salários, acesso à formação de excelência, etc. É imprescindível que encontremos, no meio da crise, algo que possibilite um outro olhar para o professor, que não o diminua, que não o deprecie, que não o desqualifique, que não avilte a sua posição, que não o culpe por todas as mazelas da educação. Pensamos ser urgente que na formação inicial se instaure uma forma de olhar esse profissional que possibilite uma outra relação entre professor, aluno e conhecimento, e que reverbere na construção identitária do professor, tal como esboçada por Geraldi (2010). Mesmo correndo o risco de assumir uma posição utópica, concordamos com o pesquisador, que há sim uma outra via para se pensar a identidade do professor. Trata-se de um caminho ainda em constituição para gestar um professor que, mesmo não sendo mais o sábio, não seja só alguém que repete o saber de outro ou aquele que se restringe a controlar um conjunto de técnicas em sala de aula (GERALDI, 2010).

Segundo Geraldi (2010, p. 92), "na crise, gesta-se o novo” e na crise por que passa a profissão de professor, a constituição de uma "nova identidade para o professor terá profundas relações com as novas formas dos conhecimentos: sempre parciais, locais, incertos”. Essa nova identidade está relacionada com o fato de que o exercício profissional do professor é também uma força propulsora de transformações, é um lugar de resistência e de força. Tais transformações podem ser operadas "pelas noções como a do professor reflexivo, pela noção do professor pesquisador, pela defesa da pesquisa-ação como forma de estar na sala de aula de todo professor, pelas parcerias construídas nas investigações participantes, etc.” (GERALDI, 2010, p. 93). Nessa visão, a identidade do professor em constituição não será mais o sábio - como produtor da ciência e da cultura -, “[...] mas um sujeito que é capaz de considerar o vivido, de olhar o aluno como um sujeito que também já tem um vivido, para transformar o vivido em perguntas” (GERALDI, 2010, p. 95).

Não podemos nos abster de fazer dialogar a noção de professor reflexivo, defendida por Geraldi, com a de professor pesquisador, proposto por Paulo Freire em Pedagogia da Autonomia:

Não há ensino sem pesquisa e pesquisa sem ensino. Esses que-fazeres se encontram um no corpo do outro. Enquanto ensino continuo buscando, reprocurando. Ensino porque busco, porque indaguei, porque indago e me indago. Pesquiso para constatar, constatando, intervenho, intervindo educo e me educo. Pesquiso para conhecer o que ainda não conheço e comunicar ou anunciar a novidade. (FREIRE, 2006[1996], p. 29).

Ainda, sobre o ser professor pesquisador, Freire escreve: 
Fala-se hoje, com insistência, no professor pesquisador. No meu entender o que há de pesquisador no professor não é uma qualidade ou uma forma de ser ou de atuar que se acresce à de ensinar. O de que se precisa é que, em sua formação permanente, o professor se perceba e se assuma, porque professor, como pesquisador. (FREIRE, 2006[1996], p. 29).

Na visão de Freire, ser pesquisador não é uma qualidade, e sim um traço constitutivo do papel de professor. No entanto, Freire não se refere à pesquisa nos moldes da academia ${ }^{4} \mathrm{e}$ sim à pesquisa do professor acerca de sua práxis. Nessa acepção, o professor precisa continuamente interrogar a sua prática com vistas a ressignificar a sua própria atuação nos contextos situados em que se busca uma educação transformadora e libertadora.

Ambas as perspectivas (de Freire e de Geraldi) dialogam, já que “[ [..] o professor é aquele que vive o tempo e o espaço da aula" (GERALDI, 2010, p. 56). Assim é que a defesa contemporânea sobre a formação de professores-pesquisadores $^{5}$ é uma realidade e uma necessidade. Talvez esse caminho (do professorpesquisador; do professor reflexivo) desobrigue o professor de atualizar-se/abastecer-se de conteúdos que estão sempre em movimento, porque o foco não está mais no objeto de conhecimento, mas nas práticas dos sujeitos situados social e historicamente (sobretudo nas práticas linguageiras).

As reflexões de Geraldi e de Freire nos ajudam a compreender os discursos dos licenciandos, que, reiteradas vezes, discursivizam o professor de LP como um sujeito que está sempre desatualizado, ou também sobre os discursos que, ainda que timidamente, mostram resistência ou uma tentativa de assimilação de novos modos de pensar a atuação docente. Os discursos sobre o professor, constituídos na história dos processos escolares, têm ressonâncias ideológicas na maneira como os licenciandos discursivizam a atuação do professor de LP hoje.

No entanto, pensamos que esse discurso construído na história pode encontrar um lugar de brecha, de contradição, de reinvenção, e talvez o professor desatualizado, recorrente na fala dos licenciandos, possa ser repensado a partir da noção do professor reflexivo e de professor pesquisador, conforme propõem Geraldi e Freire.

\section{REFERÊNCIAS}

ALLAIN, Luciana Resende; PEREIRA, Júlio Emílio Diniz. Considerações acerca do professor-pesquisador: a que pesquisa e a que professor se refere essa proposta de formação? Olhar de professor, Ponta Grossa, vol. 9, n. 2, p. 269-282, 2006. Disponível em: < http://www.revistas2.uepg.br/index.php/olhardeprofessor/article/viewArticle/1464>. Acesso em $14 / 07 / 2012$.

; [VOLOCHÍNOV, V. N.]. Discurso na vida e discurso na arte (sobre a poética sociológica). Tradução de Carlos Alberto Faraco e Cristóvão Tezza [para fins didáticos]. Versão da língua inglesa de I. R. Titunik a partir do original russo, 1926.

; [VOLOCHÍNOV, V. N.]. Marxismo e filosofia da linguagem: problemas fundamentais do método sociológico na ciência da linguagem. 11. ed. Tradução do francês por Michel Lahud e Yara F.Vieira. São Paulo: Hucitec, 2004[1929].

. Problemas da poética de Dostoiévski. Tradução do russo, notas e prefácio de Paulo Bezerra. 4. ed. Revista e ampliada. Rio de Janeiro: Forense Universitária, 2008[1963].

Questões de literatura e de estética - a teoria do romance. Tradução do russo por Aurora Fornoni Bernardini et al. São Paulo: UNESP; Hucitec, 1998[1975].

\footnotetext{
${ }^{4}$ De acordo com Allain e Pereira (2006, p. 273), "há uma forte tendência entre os acadêmicos em considerar de menor importância os saberes produzidos por professores em seus espaços de trabalho, por considerar esses conhecimentos pouco científicos, muito práticos, ou até fundamentados no senso-comum".

5 Segundo Allain e Pereira (2006), há uma crescente demanda de investigações em torno da profissionalização, identidade e saberes docentes. Contudo, ainda há no Brasil uma carência de estudos sobre o professor-reflexivo/professor-pesquisador. Para os autores, esses aspectos são de extrema importância - quando não, determinantes - na própria profissionalização dos professores e na construção de seus saberes e identidade profissional.
} 

2003[1979].

Estética da criação verbal. Tradução do russo por Paulo Bezerra. 4. ed. São Paulo: Martins Fontes,

BALTAR, Marcos Antônio Rocha. A morte do professor de português e o nascimento do agente de letramento: mudança de conteúdos na escola e mudança de currículos na universidade. Natal: Universidade Federal do Rio Grande do Norte. 2011. (Conferência proferida no VI SIMPÓSIO INTERNACIONAL DE ESTUDOS DE GÊNEROS TEXTUAIS).

FRANCHI, Carlos. Criatividade e gramática. Trabalhos em Linguística Aplicada, v. 9, p. 5-45, 1987.

FREIRE, Paulo. Pedagogia da autonomia: saberes necessários à prática educativa. 34. ed. Rio de Janeiro: Paz e Terra. 2006[1996].

GERALDI, João Wanderley. Portos de passagem. 4. ed. São Paulo: Martins Fontes, 2002〔1991].

GERALDI, João Wanderley. A aula como acontecimento. São Carlos: Pedro \& João Editores, 2010.

RODRIGUES, Rosângela Hammes. A constituição e o funcionamento do gênero jornalístico artigo: cronotopo e dialogismo. Tese (Doutorado) - Programa de Estudos Pós-Graduados em Linguística Aplicada e Estudos da Linguagem. Pontifícia Universidade Católica. São Paulo, 2001.

RODRIGUES, Nara Caetano. A construção dialógica do discurso do professor de língua portuguesa. São Carlos: Pedro \& João Editores, 2011. 232p.

SOARES, Magda. Português na escola - História de uma disciplina curricular. In: BAGNO, Marcos (Org.). Lingüistica da norma. São Paulo: Edições Loyola, 2002. p. 155-177.

Recebido em 22/o9/2013. Aprovado em 16/04/2014. 